\title{
Suvremena urologija
}

\section{Modern urology}

Prije desetak godina, točnije 2004. godine, preteča časopisa Medicina Fluminensis, tadašnji časopis Medicina (Medicina 2004;42) imao je broj posvećen urologiji u kojem je prikazano niz zanimljivih tema. U međuvremenu je došlo do značajnog napretka u urologiji, posebice u liječenju benigne hiperplazije prostate, urolitijaze i urološke onkologije.

Počeci urologije na Sušaku vezani su uz doc. dr. sc. Ljudevita Šestića koji je 1950. godine došao iz Zagreba u Rijeku, točnije na Sušak ${ }^{1}$. On je osnovao Odjel za urologiju koji je tijekom vremena bio samostalan, pa pridružen Klinici za kirurgiju, i konačno prerastao 2005. godine u Kliniku za urologiju. $\mathrm{Na}$ taj način je u 55 godina zaokružen razvoj od Odjela do Klinike. Kako su se mijenjala vremena, tako se mijenjala i patologija kojom se bavila urologija, pa smo iz razdoblja liječenja urogenitalne tuberkuloze i koraliformne nefrolitijaze došli do vremena kada je liječenje benigne hiperplazije prostate, malignih tumora urogenitalnog sustava te transplantacija bubrega njezin zasigurno najzastupljeniji dio.

Benigna hiperplazija prostate (BPH; engl. benign prostatic hyperplasia) najčešći je dobroćudni tumor u muškaraca. U obdukcijskim studijama histološka prisutnost BPH-a dokazana je kod oko 50 - 60 \% muškaraca starosti 41 - 50 godinu, no klinička simptomatologija je nešto manje učestala. Klinička simptomatologija povećava se s godinama, pa tako oko $25 \%$ muškaraca s navršenih 55 godina navodi opstruktivne simptome mokrenja, ali i do $70 \%$ muškaraca s navršenih 75 godina $^{2}$. Također prevalencija i incidencija BPH-a je globalno u stalnom porastu ${ }^{3}$. Takav porast zasigurno je u vezi sa sve starijom populacijom. Prema procjeni, do 2030. godine $20 \%$ stanovništva SAD imat će 65 ili više godina, od čega preko 20 milijuna muškaraca. Štoviše, upravo se najveći porast incidencije BPH-a predviđa u najstarijoj grupi ljudi, onoj iznad 85 godina. Trenutačne procjene govore da će broj pojedinaca starih 80 ili više godina u SAD-u porasti s 9,3 milijuna 2000. godine na čak 19,5 milijuna 2030 . godine, što je porast od preko $100 \%$. Slična tendencija postoji i u europskim zemljama. $\mathrm{S}$ obzirom na to da klinička značajnost BPH-a raste sa starošću, može se očekivati kako će jedna velika grupa muš- 
karaca trebati urološko liječenje. Ono će u prvome redu biti medikamentozno, a manje kirurško. Broj operacija prostate, prvenstveno zlatnog standarda za operacijsko liječenje (transuretralna resekcija prostate - TURP) u opadanju je. Taj pad prisutan je već više godina i kreće se od $43 \%$ u SAD-u (razdoblje od 1987. do 1994.) do 31,6\% u Velikoj Britaniji (razdoblje od 1990. do 2000.) Uzrok tome je razvoj suvremene medikamentozne terapije. Prije dvadesetak godina koristili su se samo neselektivni blokatori alfa-adrenergičkih receptora koji su imali i česte nuspojave. No, pronalazak inhibitora 5-alfa-reduktaze (finasterid i kasnije dutasterid) te uroselektivnih blokatora alfa adrenergičkih receptora (tamsulosin) doveo je do prave revolucije u liječenju $\mathrm{BPH}-\mathrm{a}^{6-12}$. $\mathrm{U}$ današnje vrijeme ovi su lijekovi zlatni standard u liječenju BPH-a, ali pojavio se i niz drugih lijekova (antagonisti muskarinskih receptora, dezmopresin, agonisti beta-3 adrenergičkih receptora, inhibitori 5-fosfodiesteraze) koji se koriste u određenim indikacijama² ${ }^{2}$ Od liječnika će se tražiti da od niza lijekova odabere one koji će biti najbolji za pacijenta, poput današnjeg određivanja terapije za arterijsku hipertenziju.

Urološka onkologija, tj. liječenje malignih tumora urogenitalnog sustava danas predstavlja segment koji je najzastupljeniji u stacionarnom liječenju. To se ponajviše odnosi na karcinom prostate, mokraćnog mjehura i bubrega. Zanimljivo je kako je početkom 70-ih godina u Rijeci broj pacijenata $\mathrm{s}$ karcinomom bubrega bio $2-3$ godišnje ${ }^{13}$. Još se sjećamo riječi naših starijih kolega koji su sada u mirovini koji su nam govorili kako su u to vrijeme takve dijagnoze bile toliko rijetke da su pacijente znali poimence. $U$ današnje vrijeme broj operiranih pacijenata na našoj Klinici zbog karcinoma bubrega kreće se oko 50 - 60. Liječenje karcinoma bubrega također se djelomično promijenilo. Od koncepta radikalne nefrektomije evoluiralo se prema poštednoj kirurgiji bubrega, tako da se preporučuje odstranjenje tumora bubrega s okolnim zdravim parenhimom, ali uz očuvanje preostale nefronske mase. Time se ne utječe na onkološki ishod liječenja, a čuvanjem nefronske mase smanjuje se mogućnost razvoja kronične bubrežne bolesti koja dovodi do hipertenzije, anemije, neuropatije, smanjene kvalitete života i povećanog rizika od razvoja kardiovaskularnih bolesti koje su najznačajniji čimbenik morbiditeta i mortaliteta u ove skupine pacijenata ${ }^{14-16}$.

Onkološko liječenje karcinoma bubrega također se znatno promijenilo. Radioterapija i klasična kemoterapija nemaju značajniji utjecaj na stanice najčešćeg adenokarcinoma bubrega. No, razvoj „ciljane terapije” donio je značajnu promjenu u liječenju metastatske bolestiti,18. Radi se o lijekovima koji blokiraju točno određenu molekulu koja ima ulogu u tumorogenezi te se zbog toga ti lijekovi nazivaju i „pametni lijekovi”. Posebno se izdvajaju lijekovi koji djeluju putem vaskularnog endotelnog čimbenika rasta (VEGF; engl. vascular endothelial growth factor) odnosno njegovog receptora (VEGFR; engl. vascular endothelial growth factor receptor). „Ciljana terapija" dovela je do značajnog produljenja života tih pacijenata, a da nije značajnije utjecala na kvalitetu života (što je slučaj kod citotoksične terapije koja se, primjerice, primjenjuje kod karcinoma dojke). Karcinom mokraćnoga mjehura također je čest na području Rijeke i okolice, te bi bilo zanimljivo ispitati mogući uzrok ovom našem opažanju. Preko $75 \%$ pacijenata s karcinomom mjehura ima neinvazivni („površni”, T1) karcinom čiji je glavni problem relativno velika sklonost recidiviranju, ali i mogućnost prelaska u invazivni karcinom (T2 i T3), što zahtijeva radikalno kirurško liječenje. Imunoterapija (primarno intravezikalna instilacija BCG-a) pokazala se učinkovitom metodom u sprječavanju recidiviranja i progresije ove bolesti ${ }^{19-22}$. No, u slučaju progresije bolesti neophodno je učiniti radikalnu cistektomiju i neku od urinarnih diverzija. Nažalost, samo u malenog broja pacijenata možemo učiniti ortotopnu derivaciju urina. Velika većina pacijenata ima urostomu, odnosno urin izlazi slobodno na kožu putem segmenta tankog crijeva (operacija po Brickeru) ili samog uretera koji je izveden na kožu (ureterokutanostomija). To je i razlog zbog kojeg su naše sestre koje se bave urostomijama, uz brojne slikovne prikaze, obradile upravo tu problematiku. Naime, broj tih pacijenata raste i izvanbolnički liječnici i medicinske sestre daleko će se više susretati s pacijentima u kojih je učinjena urostomija, pa je potrebno provoditi kontinuiranu edukaciju.

Karcinom prostate najučestaliji je karcinom u Primorsko-goranskoj županiji, dok je u Hrvatskoj na trećem mjestu ${ }^{23}$. Po smrtnosti taj je karcinom na prvom mjestu u našoj županiji. Mišljenja smo 
kako je uzrok tako visokoj incidenciji relativno „visoki zdravstveni standard" u našoj županiji, gdje se velika većina muškaraca šalje na urološki pregled uz određivanje PSA-a nakon navršene 50. godine života (jedna vrsta probira). Dodatni važni čimbenik je dobro razvijena urološka služba (prvenstveno u KBC-u Rijeka). Povećani broj novootkrivenih pacijenata $s$ karcinomom prostate sa sobom nosi i nove izazove ${ }^{24-26}$. Kako odrediti koji je karcinom prostate agresivan i predstavlja prijetnju za zdravlje pacijenata, a koji je klinički beznačajan? Kako spriječiti moguće suviše agresivno liječenje pacijenata? To su pitanja koja zahtijevaju dodatna istraživanja kako bismo odabrali najbolje liječenje za pojedinog pacijenta.

Napredak urologije vidljiv je i u liječenju urolitijaze. Prije samo dvadesetak godina kamenac u ureteru značio je hitan operacijski zahvat $s$ otvorenim pristupom, lumbotomijskim rezom, duljim oporavkom, zaostalim bolovima nakon operacije, razvojem poslijeoperacijskih hernija itd. Endourološke metode, kao izvrstan primjer minimalno invazivnih metoda, to su promijenile. U ovom smo broju predstavili miniperkutanu nefrolitotripsiju i izvantjelesno mrvljenje kamenaca kao izuzetno efikasne metode za liječenje urolitijaze, a koje koristimo u našem radu.

Ujedno, kao i u drugim specijalnostima, i u urologiji je sve značajnija multidisciplinarnost i suradnja među različitim strukama. Stoga smo u ovom broju pozvali i naše kolege radiologe, patologe, onkologe, ginekologe i psihijatre. Naša suradnja je svakodnevna i jedino na taj način može se pružiti adekvatna skrb našim pacijentima. No, ne zaboravimo, naši pacijenti su jedna cjelina, a ne podijeljeni po organskim sustavima. Izuzetno nam je drago da su nam se u našim tekstovima pridružile i naše medicinske sestre. One su uvijek prve uz pacijenta i njihov je doprinos u svakodnevnoj skrbi nezamjenjiv.

Zaključno, urologija je dinamična, multidisciplinarna struka koja se brzo razvija. Želja nam je bila prikazati stanje urologije u ovom trenutku, ali isto tako naglasiti i snagu sadašnje Klinike za urologiju. Vjerujemo da će čitatelji naći mnoge teme koje ih interesiraju.

Na kraju, zahvaljujemo svim autorima na uloženom trudu i vremenu za pisanje kvalitetnih i vrijednih članaka, kao i recenzentima, čije su korisne sugestije i komentari pridonijeli da ovaj broj bude, vjerujemo, zanimljiv, suvremen, ali i razumljiv širem krugu čitateljstva.

doc. dr. sc. Josip Španjol doc. dr. sc. Dean Markić Klinika za urologiju, KBC Rijeka, Rijeka

\section{LITERATURA}

1. Fučkar Ž. Povijest urologije na Sušaku. Rijeka: Digital point, 2006.

2. Gravas S, Bach T, Bachmann A, Drake M, Gacci M, Gratzke et al. Guidelines on the management of non-neurogenic male lower urinary tract symptoms (LUTS), incl. Benign Prostatic Obstruction (BPO). Arnhem, Nizozemska: European Association of Urology Guidelines, 2016.

3. Wei JT, Calhoun E, Jacobsen SJ. Urologic diseases in America project: Benign prostatic hyperplasia. J Urol 2008;179:S75-80.

4. Centers for Disease Control and Prevention (CDC). Trends in aging-United States and worldwide. MMWR Morb Mortal Wkly Rep 2003;52:101-4.

5. Wilson JR, Urwin GH, Stower MJ. The changing practice of transurethral prostaectomy: a comparison of cases performed in 1990 and 2000. Ann R Coll Surg Engl 2004;84:428-31.

6. Chapple CR, Wyndaele JJ, Nordling J, Boeminghaus F, Ypma AF, Abrams P. Tamsulosin, the first prostate-selective alpha $1 \mathrm{~A}$-adrenoreceptor antagonist. A meta-analysis of two randomised, placebo-controlled, multicenter studies in patients with benign prostatic obstruction (symptomatic BPH). European Tamsulosin Study Group. Eur Urol 1996;29:155-67.

7. Rittmaster RS, Norman RW, Thomas LN, Rowden G. Evidence for atrophy and apoptosis in the prostates of men given finasteride. J Clin Endocrinol Metab 1996;81: 814-9.

8. Lepor H, Williford WO, Barry MJ, Brawer MK, Dixon CM, Gormley $\mathrm{G}$ et al. The efficacy of terazosin, finasteride, or both in benign prostatic hyperplasia. N Engl J Med 1996;335:533-9.

9. Michel MC, Vrydag W. Alpha1-, alpha2- and beta-adrenoceptors in the urinary bladder, urethra and prostate. Br J Pharmacol 2006:147:S88-119.

10. Michel MC, Mehlburger L, Bressel HU, Goepel M. Comparison of tamsulosin efficacy in subgroups of patients with lower urinary tract symptoms. Prostate Cancer Prostatic Dis 1998;1:332-5.

11. Roehrborn CG, Boyle P, Nickel JC, Hoefner K, Andriole. Efficacy and safety of a dual inhibitor of 5-alpha-reductase types 1 and 2 (dutasteride) in men with benign prostatic hyperplasia. Urology 2002;60:434-41.

12. Roehrborn CG, Siami P, Barkin J, Damiao R, Major-Walker K, Morrill B et al. The effects of dutasteride, tamsulosin and combination therapy on lower urinary tract symptoms in men with benign prostatic hyperplasia and prostatic enlargement: 2-year results from the CombAT study. J Urol 2008;179:616-21.

13. Markić $D$, Oguić $R$, Sotošek $S$, Krpina $K$, Ahel J, Materljan $M$ et al. Incidencija, klinička evaluacija i kirurško liječenje pacijenata s karcinomom bubrega: 40-godišnje isku- 
stvo u Kliničkom bolničkom centru Rijeka. Medicina Fluminensis 2017;53:376-82.

14. Leibovich BC, Blute ML, Cheville JC, Lohse CM, Weaver $A L$, Zincke $H$. Nephron sparing surgery for appropriately selected renal cell carcinoma between 4 and $7 \mathrm{~cm}$ results in outcome similar to radical nephrectomy. J Urol 2004;171:1066-70.

15. Crépel $M$, Jeldres $C$, Perrotte $P$, Capitanio $U$, Isbarn $H$ Shariat SF et al. Nephron-sparing surgery is equally effective to radical nephrectomy for T1BNOMO renal cell carcinoma: a population-based assessment. Urology 2010;75:271-5.

16. Markić D, Valenčić M, Španjol J, Materljan M, Fučkar D. Renal function outcome after nephrectomy for kidney cancer in elderly patients. Coll Antropol 2011;35:121-4.

17. Motzer RJ, Michaelson MD, Redman BG, Hudes GR, Wilding G, Figlin RA et al. Activity of SU11248, a multitargeted inhibitor of vascular endothelial growth factor receptor and platelet-derived growth factor receptor, in patients with metastatic renal cell carcinoma. J Clin Oncol 2006;24:16-24.

18. Escudier B, Eisen T, Stadler WM, Szczylik C, Oudard S, Siebels $M$ et al. Sorafenib in advanced clear-cell renalcell carcinoma. N Engl J Med 2007;356:125-34.

19. Böhle A, Bock PR. Intravesical bacillus Calmette-Guerin versus mitomycin $\mathrm{C}$ in superficial bladder cancer: formal meta-analysis of comparative studies on tumour progression. Urology 2004;63:682-7.
20. Saint F, Salomon L, Quintela R, Cicco A, Hoznek A, Abbou $C C$ et al. Do prognostic parameters of remission versus relapse after bacillus Calmette-Guerrin (BCG) immunotherapy exist? Analysis of a quarter century of literature. Eur Urol 2003;43:351-61.

21. Fernandez-Gomez J, Solsona E, Unda M, Martinez-Pineiro L, Gonzalez M, Hernandez R et al. Prognostic factors in patients with non-muscle-invasive bladder cancer treated with bacillus Calmette-Guerin: multivariate analysis of data from four randomized CUETO trials. Eur Urol 2008;53:992-1002.

22. Sylvester RJ. Bacillus Calmette-Guerin treatment of non-muscle invasive bladder cancer. Int J Urol 2011;18: 113-20.

23. Španjol J, Maričić $A$, Cicvarić, $T$, Valenčić $M$, Oguić $R$, Tadin T et al. Epidemiology of prostate cancer in the mediterranean population of Croatia - a thirty-three year restrospective study. Coll Antropol 2007;31:235-9.

24. Bastian PJ, Mangold LA, Epstein JI, Partin AW. Characteristics of insignificant clinical T1c prostate tumors. A contemporary analysis. Cancer 2004;101:2001-5.

25. Jeldres C, Suardi N, Walz J, Hutterer GC, Ahyai S, Lattouf $J B$ et al. Validation of the contemporary Epstein criteria for insignificant prostate cancer in European men. Eur Urol 2008;54:1306-13.

26. Sheng F, Oon SF, Watson RW, O'Leary JJ, Fitzpatrick JM. Epstein criteria for insignificant prostate cancer BJU Int 2011;108:518-25. 